A Study of the Movement of Spiritual Inner Awareness 
This page intentionally left blank 


\title{
A Study of the Movement of Spiritual Inner Awareness
}

\author{
Religious Innovation and \\ Cultural Change
}

Diana G. Tumminia and

James $R$. Lewis

palgrave macmillan 


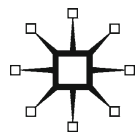

A STUDY OF THE MOVEMENT OF SPIRITUAL INNER AWARENESS

Copyright (C) Diana G. Tumminia and James R. Lewis, 2013.

Softcover reprint of the hardcover 1st edition 2013 978-1-137-37418-9

All rights reserved.

First published in 2013 by

PALGRAVE MACMILLAN ${ }^{\circledR}$

in the United States-a division of St. Martin's Press LLC,

175 Fifth Avenue, New York, NY 10010.

Where this book is distributed in the UK, Europe and the rest of the world, this is by Palgrave Macmillan, a division of Macmillan Publishers Limited, registered in England, company number 785998, of Houndmills, Basingstoke, Hampshire RG21 6XS.

Palgrave Macmillan is the global academic imprint of the above companies and has companies and representatives throughout the world.

Palgrave ${ }^{\circledR}$ and Macmillan ${ }^{\circledR}$ are registered trademarks in the United States, the United Kingdom, Europe and other countries.

ISBN 978-1-349-47687-9 ISBN 978-1-137-37419-6 (eBook)

DOI $10.1057 / 9781137374196$

Library of Congress Cataloging-in-Publication Data is available from the Library of Congress.

A catalogue record of the book is available from the British Library.

Design by Newgen Knowledge Works (P) Ltd., Chennai, India.

First edition: November 2013

109876554321 
Contents

List of Figures and Tables vii

Introduction ix

Chronology xxxiii

1 What Is MSIA? 1

2 Entrance into the Field 23

3 Beginnings $\quad 47$

4 Prana 65

5 How They Came into the Movement 83

6 Being a Minister 105

7 Charisma: John-Roger and John Morton 123

8 In Your Dreams 143

9 Survey and Comparative Demographics 157

10 Stereotypes and Social Conflict 173

$\begin{array}{ll}11 \text { Conclusion } & 187\end{array}$

$\begin{array}{ll}\text { Appendix } & 197\end{array}$

Notes 199

$\begin{array}{ll}\text { Glossary } & 203\end{array}$

$\begin{array}{ll}\text { References } & 221\end{array}$

$\begin{array}{ll}\text { Index } & 229\end{array}$ 
This page intentionally left blank 


\section{Figures and Tables}

\section{Figures}

0.1 John-Roger pictured sitting on a pyramid in Egypt xiii

1.1 John-Roger traveled to the Acropolis to place Light Columns

3.1 A bearded John-Roger conducts a seminar in the early 1970s 60

4.1 Prana serves as the main landmark building of MSIA 66

7.1 John Morton and John-Roger often conducted seminars together after 1988 until about 2008

7.2 John Morton received the designation of Mystical Traveler from John-Roger in 1988

Tables

9.1 Gender 158

9.2 Decade of birth 160

9.3 Ages of MSIA recruits by five-year period 160

9.4 Marital status 161

9.5 Number of children 162

9.6 Highest degree of education 163

9.7 Occupation 165

9.8 Income 166

9.9 Political orientation 168

9.10 Religious heritage 169

9.11 Length of membership 170

9.12 Initiatory level 171 
This page intentionally left blank 


\section{Introduction}

This book combines the efforts of two academics in this study of a new religion, the Movement of Spiritual Inner Awareness (MSIA), based in southern California. James R. Lewis and Diana G. Tumminia blend their ethnographic labors and years of research into a rich portrait of modern faith by pooling their information into one volume to produce a description of this emergent form of spirituality and religious experience. They present a descriptive sociological snapshot of MSIA that enhances the complex picture of new religious expressions in the twenty-first century.

Religion scholars recognize James R. Lewis for charting the modern landscape of new religions with works on UFO spirituality, neo-paganism, the New Age movement, as well as numerous other noteworthy works on other new religious movements (NRMs). When very little was known about MSIA, Lewis began his landmark research of MSIA in 1994 by conducting interviews, collecting historical data, distributing surveys, and doing participant observation. Lewis spent over a year in the field talking with members and leaders, besides conducting workshops and experiencing MSIA culture. That research culminated in Seeking the Light (Lewis 1998b), a monograph well received for its firsthand account of MSIA and its teachings. Some critics thought that the group had converted Lewis, but that was not the case. He remains an interested outsider, who has gone on to other projects that investigate newer spiritual expressions, such as UFO religions, Satanism, and New Age groups to name a few. In this volume, Lewis updates his previous research with a 2012 survey of MSIA members.

In separate investigations of social movements, Diana G. Tumminia studied groups such as American Atheists, American Zen, Wicca, Hare Krishna (ISKCON), and Unarius (a UFO contactee religion). Because her participant observation of MSIA dates back to 1978, she 
could contribute qualitative descriptions, interview responses, literature reviews, and other background information to the study. During the course of the research, she became a member of MSIA, which allowed her to understand some of the complexities inherent in the group. Many academics argue the benefits and drawbacks of membership when doing ethnographic research (Emerson 1988). Some disdain the lack of objectivity, while others stress the value of insider information. Participant observers have produced many famous sociological studies. For example, William Foote Whyte wrote the timeless Street Corner Society (1955) and Elliot Liebow penned the classic Tally's Corner (1967). Such methodology crosses over into studies of religion; some excellent examples are E. Burke Rockford's Hare Krishna in America (1985), James Damrell's Seeking Spiritual Meaning (1977), and David Preston's The Social Construction of Zen Practice (1988). Tumminia worked intensely to bring this MSIA study up-to-date by conducting interviews, doing ethnographic fieldwork, and documenting research from 2005 until the present. Here, Tumminia applies her working knowledge of the group to detail the subjective meanings that members use to create their understandings of themselves and their religion.

\section{Introducing MSIA}

As a self-identified ecumenical church, MSIA (pronounced by saying each letter in the acronym, M. S. I. A.) uses the philosophies and practices of many major religions, metaphysical traditions, and popular culture. Rarely do older members refer to it as Messiah, which should not be misconstrued as salvation from a particular leader, but rather the sacredness inside every person. The MSIA website (http://www. msia.org) provides the reader with a firsthand look at what the church does. At the website, one can peruse the lists of books, downloads, and CDs that explain the teachings, or one can watch video-streamed talks by leaders online. Clicking on the "Prayer List," one can type in a name of someone who needs divine assistance. Through cyberspace, MSIA invites others to participate in its circle of love and transcendence. This virtual window on their philosophy extols the joys of prosperity, peace, and fellowship that emanates from a heavenly source.

Publishers suggested the present title of the book as they thought the original title flowery. The original title, The Purple Rose, captured some of the organic nature in which new religions grow. It stems from 
a symbol in MSIA, purple for the color of light that indicates the presence of the spiritual teacher and the rose as a living manifestation of a loving creation. For such unfamiliar symbols and words, a glossary in the back of the book provides the reader with helpful definitions. The glossary definitions closely coincide with the MSIA's meaning system as much as possible in the case of terms specifically used in the group. Definitions, of course, may differ from person to person.

Within the text, some fictitious names conceal the identities of members, ex-members, and interviewees to guard their anonymity. Names and other information that are part of public documents have been kept the same in order that others could utilize the research in the future. During the course of the writing, the authors conversed with MSIA representatives and regular members in a process of rechecking facts and interpretations. Sociology calls this method, member validation. MSIA's cooperation became essential to constructing the book. Member feedback enables the researchers to come closer to understanding the enacted world of everyday life in distinctive groups, and thus, in turn, create windows into those social enclaves of sacred discourse. In this regard, the authors acknowledge everyone's cooperation, especially Mark Lurie, Laren Bright, Candace Semigram, Carol Jones, John Morton, Elda and Delile Hinkins, and the dozens of people who allowed themselves to be interviewed.

The general mood of the book leans toward the perspectives of the cultural relativism of spiritual experience and social history of new religions in Western society. Cultural relativism is a research stance that reserves judgment on cultural practices. Consequently, from this perspective, all religions stand as equals and member perspectives ought to be respected as part of the human experience without derision. This means that the book is not meant to be an exposé or a debunking expedition, despite the fact the many older and much cited writings on MSIA tend to voice concerns of mind control and have spawned a pattern of labeling and suspicion. In doing so, scholars lost track of decades of this viable spiritual presence in American religion. The tenor of the text focuses rather on a descriptive study of localized knowledge and cultural practices, although issue is taken with the stereotyping of new religions.

From a scholarly perspective, one religion looks as fanciful or as true as another, given the human propensity to seek for other realities beyond the physical plane. Our aim was to capture some MSIA history and member testimonies about their spiritual journeys for posterity. Our concerns and foci examine the cultural production and innovation, rather than 
the so-called disparaging nature of cults. Nonetheless, the sociohistorical particulars of MSIA will mention ex-members and pertinent controversies, while also remarking upon how members carried on.

MSIA functions similar to any religion, as it provides inspiration, especially in times of personal trouble, while also explaining the meaning of life events. It performs life-marking services, such as marriage ceremonies, baby blessings, baptism, and Circle of Light for the dying, among a host of other services. The church organizes meetings and trips, in conjunction with combining resources of many to make available publications, buildings, sacred places, retreat grounds, and community. This book addresses its ordinariness alongside its specificity of history.

\section{Historic Precursors to MSIA}

The many and varied roots of MSIA will become more evident as the succeeding chapters of the book unfold. This section sketches an ideological heritage that may be of more interest to scholars than casual readers. MSIA's eclecticism mirrors a postmodern receptivity to a bricolage of various formerly disparate religious themes as it retools for twenty-first century concerns utilizing a globalized collection of what spirituality addresses within the psyche and the society. It ranks as a relatively new religion from the California scene, now making its mark on the world; it embodies an eclectic theology and philosophy that defines each member as the Light (capitalized), divine sparks of God. According to MSIA, each individual on the planet is involved in his or her own radiant movement of spiritual inner awareness, of which the church is only a dim outward reflection. One member quipped, "MSIA is a spiritual garden where purple roses grow [meaning souls blossom in its Light]." To outsiders, it may look like part playground and part meditation center, although its intention is to give spiritual wake-up calls to sleepy souls. Sometimes serious and often silly, members find their own levels of involvement keeping in mind that soul liberation or reincarnation could be the outcome of their attitudes and actions. MSIAers believe in health, wealth, happiness, prosperity, and having a good time, in addition to being generous to others and performing acts of charitable service.

From a sociohistorical perspective, MSIA stands as an amazing synthesis of many different, preexisting practices and philosophies, over and above the purported revealed teachings of the Mystical Traveler. Founder John-Roger created a here-and-now quality. The transcriptions 
of recordings of all his talks and in turn John Morton, his successor, continue to be the focus of books, discourses, and instruction. Since they number in the thousands, the talks (seminars as they are called) hold the teachings and will be the gospels of the future. From recorded talks, one can learn from John-Roger's often humorous sayings. Such John-Rogerisms may be as simple as, "Life is like that." Then again they may be folksy, for example, "Golly. Gee-whiz. Don't shoot yourself out of the saddle." Another John-Rogerism goes like this: "What are you doing? Chewing your guts into fiddle strings to see what tune they will play?" In addition, people familiarize themselves with John Mortonisms, "Karma is sort of like that cartoon character Baba Looey. It keeps following you around." An additional John Mortonism comes in the form of a country and western ditty: "We're riding in the bus tracks of Jesus." Such is some of the nature of its emergent wisdom. As part of their ministries, John-Roger and John Morton travel with various followers throughout the world blessing the land (see figure 0.1 ).

MSIA takes from established traditions and more, adding improvisational content relevant to the times, including an emphasis on the "practical spirituality" of self-help psychology and the spiritual lessons that can be found in television and movie plots. As a newer

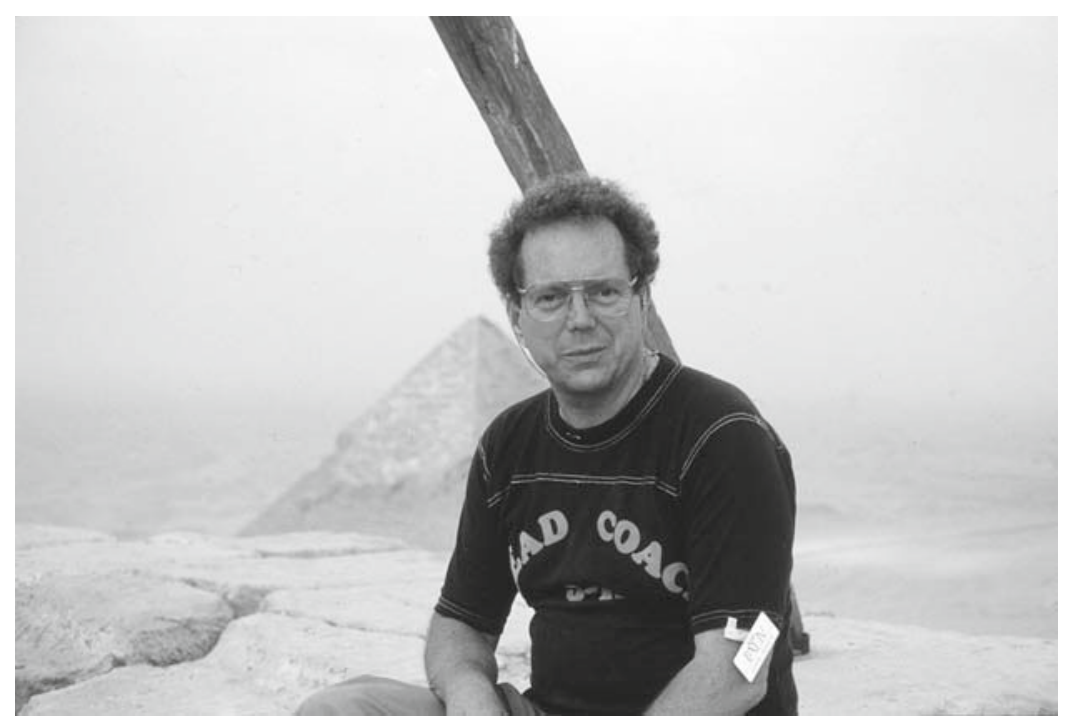

Figure 0.1 John-Roger pictured sitting on a pyramid in Egypt during a Peace Awareness Training (PAT) probably during the 1980 s. 
American religion, MSIA is not unique in this respect because many alternative spiritualties show long ideological roots that go back to a diffusion of Eastern philosophies out of Asia and the infusion of iconoclastic attitudes into the mysticism from the West. The principal components of this synthesis comes from India's Sant Mat tradition (Lewis 1998b) that is imbued with Hindu and Sikh concepts, esoteric Christianity (Introvigne 1998), New Thought ideology (DeChant 1999), and the West's occult-metaphysical subculture that gave birth to the New Age milieu (Lewis 1998a). Each of these components will be discussed after a brief look at the cultural exchange that took place between emergent American spiritualties and Eastern mysticism.

Rawlinson (1997) notes several periods of cultural exchange with Eastern religions: the early Western seekership 1875-1916, the first period of growth 1917-1945, the era of propagation 1946-1962, the period of full bloom from 1963 to the present. Even as early as 1785, Charles Wilkins translated Hinduism's Bhagavad Gita (Song of God), which found an audience in the American transcendentalists Henry David Thoreau and Ralph Waldo Emerson. In 1832, a Hindu teacher Rammohan Roy translated the Upanishads, offering it as a viable philosophy for the West (Rawlinson 1997:380). At the Chicago World's Fair, Swami Vivekananda spoke at the World Parliament of Religions in 1893, and he went on to start the Vedanta Society in New York in 1894. The well-known Swami Yogananda set up the Self-Realization Fellowship (SRF) in Los Angeles in 1925.

As Hinduism started to travel across the ocean, adventurous Westerners in turn looked East, eventually searching Asia and the Middle East for new religious experiences. Some Westerners actually became spiritual teachers themselves when they returned from their journeys (Rawlinson 1997). Western seekers who found Eastern teachers spun off popular tales of their discoveries of perfect spiritual masters. Fictional novels such as The Razor's Edge by W. Somerset Maugham and Lost Horizon by James Hilton gave readers an idealist hope for a here-and-now salvation through Eastern mysticism, an image that reached the masses when Hollywood made films of these stories. Real seekers such as Julian Johnson (Path of the Masters 1939/1963) brought new information about far-off gurus and their teachings to the receptive ears of would-be neophytes. Johnson's book explained the previously obscure Radhasoami sect to many.

Principally, theosophy spliced Eastern and Western myths and mysticism. From theosophy and its contemporary, spiritualism, the successive milieus inherited a taste for "inspired" knowledge gained 
from altered states of trance, channeling, visions, and conversations with ethereal ascended masters (Melton 1990). Theosophy passed on ideas about lost continents (e.g., Atlantis and Lemuria), reincarnation, karma, the Great White Brotherhood, and idiosyncratic spiritual hierarchies. A recognized influence on what was to come, Madame Blavatsky established the Theosophical Society in 1875 (Melton 1990; Rawlinson 1997), which served as a resource for many later alternative forms of metaphysical teachings, including ensuing NRMs that relied on the words of invisible mahatmas (it literally means great souls, but figuratively means great teachers). Some offshoots are anthroposophy, the Arcane School, and the I AM movement; moreover, groups that organized much later on, such as the Aetherius Society, Unarius, and the Summit Lighthouse (formerly the Church of the Universal and Triumphant), also show the diluted influence of some aspects of Theosophy. East met West in Theosophy-influencing subsequent ideologies to enter into mixed marriages of divine opposites.

Several push/pull factors fostered the preliminary intermingling of Eastern and Western religions in North America. As a push factor, various religions wanted to expand to the West, for instance, Radhasoami (Harper 1972; Juergensmeyer 1991) and ISKCON (Rochford 1984) to name only two out of dozens of examples. By the 1930s, Radhasoami's Sawan Singh sought and found an international audience. His disciple, Kirpal Singh, toured abroad after 1948 reaching thousands; he founded the related sect, Ruhani Satsang, in 1951 in India and visited the United States in 1955 (Lane 1993). In 1965, ISKCON's A. C. Bhaktivedanta Swami Prabhupada carried out his spiritual master's instructions to bring Hare Krishna to the West when he arrived as elderly man in New York City (Rochford 1984). Dispute the problems caused by Westerners succeeding Prabhupada as regional gurus, ISKCON endured and now is a permanent fixture of Western society and India. Similarly, some sects of Eastern Buddhism, Sikhism, and Sufism hoped to gain converts in the West (Rawlinson 1997; Partridge 2004). In due course, most imported religions made concessions, large and small, to Westerners in terms of relaxing gender boundaries and ascetic requirements.

A pull factor came from certain sectors of seekers who found conventional religions lacking in the West. By the twentieth century, India's colonial history with the British Empire ushered in an educated English-speaking middle class who offered their services to countless gurus. Translated works grew to be fairly available by the end of the 1950s. English-speaking countries heartily consumed the 
ever-increasing number of translations of arcane religious thought particularly from India, while Chinese and Japanese translations quickly followed suit. There had been strong subcultures of marginal religions for a long time in the West, but the 1960s and 1970s exploded with a taste for Eastern mysticism (Needleman 1972; Glock and Bellah 1976; Rawlinson 1997). In 1967, the publicity generated by the Beatles who went to see Maharishi Yogi in Wales (Partridge 2005) and then at his Indian ashram at Rishikesh at the foot of the Himalayas in 1968 helped in small part to make Eastern spirituality trendy and hip. But even as they posed for photos, the Beatles seemed to be reflecting a real growing interest with foreign religions rather creating the trend itself.

Until the 1960s, Asian spiritual masters faced pressures by racist American immigration laws. Anti-Asian immigration policies had barred most Asian teachers from coming to the United States to stay until reforms were instituted (Melton 1992; Rawlinson 1997). After policies became less restrictive in 1965, many foreign spiritual masters came and found substantial followings (e.g., Transcendental Meditation, ISKCON, and Divine Light Mission-now called Elan Vital); nevertheless, the cultural stage had already been set to allow Western teachers to preach Eastern philosophy.

\section{Distant Influences from Hinduism}

Embedded within its multiplicity of spiritual beliefs, MSIA embodies generic Hindu ideas reflecting the twentieth-century diffusion from East to West. As blanket term, Hinduism represents a conflation of different teachings and practices (Waterstone 1995; Feuerstein 1996; Hiriyanna 1996; Leaman 1999) developed throughout assorted epochs and within competing worldviews from its roots in indigenous religious sacrifice to various schools of otherworldly thought. The Indian subcontinent nurtured a broad diversity of beliefs and practices around karma and reincarnation with extremely ancient roots that would travel west centuries later.

The early religious vision of the Vedas (ca. 1200 BCE) unlike that of later Hinduism focused very much on this world (Waterstone 1995). Hindu mythology tells of the god Brahma emanating sound to create all realms of existence. According to Waterstone (1995: 16), "Because they contain the sacred syllables from which gods and mortals were born, the Vedas are thought to have preceded the universe, itself created from the sacred syllable Om." Johnson (1939/1963: 65) states 
that the Nada-Bindu Upanishad, an add-on to the original text of the Rig Veda, speaks of inner sacred sounds that can be heard presumably in meditation. This would much later develop into a yogic practice called nada yoga. Maha-Nada would come to mean the Audible Life Stream of the Sound of God or the Great Music (Johnson 1939/1963). These brief references to sacred sound comprise only a tiny portion of the wisdom of the Vedas, nevertheless, the conceptualization of what is later called the Sound Current would show up in subsequent forms of theology.

On the earthly plane, the priesthood ritually invoked the gods to improve situations in this life, and then sages started asking questions about the ultimate meaning of life. As an extension, there developed ideologies centered upon one's release or liberation (moksha) from the cycle of death and rebirth (samsara). The various disciplines that are collectively referred to as yoga developed out of this introspective turn. A new vision of reality that was first expressed in the Upanishads (Easwaran 1987; Waterstone 1995) superseded the original Vedic worldview. This new viewpoint emerged in a set of religious texts collectively referred to as the Upanishads (ca. seventh to fifth century BCE) found at the end of the Vedas. The Upanishads postulated an eternal, changeless core of the self-the atman-the soul. This soul or deep self was viewed as being identical with the unchanging Godhead, referred to as Brahman. The equating of the deep self with the ultimate is expressed in innumerable ways, for instance, in the Upanishadic concept Tat tvam asi (Thou art that!), meaning the essential indescribable essence of everything (Johnson 1939/1963: 321; Leaman 1999). Thus, each individual contains a spark of God's essence.

Untouched by the variations of time and circumstance, the atman was, all the same, entrapped in the world of samsara (Leaman 1999). Samsara refers to the process of death and rebirth (reincarnation) through which we are trapped in this world. Unlike many Western treatments of reincarnation, which make the idea of coming back into body after body seem exotic, desirable, and even romantic, other strains such as Hinduism, Buddhism, and other Eastern religions portray the samsara process as unhappy. Life in this world is suffering. What keeps us trapped in the samsara cycle is the law of karma. In its simplest form, this law operates impersonally like a natural law, ensuring that every good or bad deed eventually returns to the individual in the form of reward or punishment commensurate with the original deed. It is the necessity of "reaping one's karma" that compels human beings to 
take rebirth (to reincarnate) in successive lifetimes. In other words, if one dies before reaping the effects of one's actions as most people do, the karmic process demands that the soul comes back in a future life. Coming back into another lifetime also allows karmic forces to reward or punish one through the circumstances in which one is born. For example, an individual who was generous in one lifetime might be reborn as a wealthy person in her or his next incarnation.

Moksha is the traditional Sanskrit term for release or liberation from the endless chain of deaths and rebirths. In the Eastern religious tradition, it represents the supreme goal of human strivings. Reflecting the diversity of Hinduism, liberation can be attained in a variety of different ways, from the proper performance of certain rituals to highly disciplined forms of yoga. In the Upanishads, it is proper knowledge, in the sense of insight into the nature of reality, which enables the aspiring seeker to achieve liberation from the wheel of rebirth (Hiriyanna1996; Leaman 1999). What happens to the individual after attaining moksha? In Upanishadic Hinduism, the individual atman merges into the cosmic Brahman. A traditional image is that of a drop of water which, when dropped into the ocean, loses its individuality and becomes one with the ocean. While this metaphor is widespread, it does not quite capture the significance of this merger. Rather than losing one's individuality, the Upanishadic understanding intimates that the atman is never separate from Brahman; for this reason, individuality is illusory and liberation is simply waking up from the dream of separateness.

As a later development within Hinduism, devotionalism rejected the impersonalism of the intellectual emphasis of the Upanishads. Instead, followers of such philosophy approached God as a personal, supremely loving deity who would respond to devotional worship. Referred to as bhakti or bhakti yoga, such personal devotion fixated upon sectarian gods (e.g., the Hare Krishna Movement, an offspring of Caitanyaism) in some cases and also veneration of the guru. During the devotional revivals that swept across South Asia during the Indian Middle Ages, a strand of this type of spirituality spilled over into the Sant Mat tradition. Like other devotional paths, this new tradition built itself upon devotion to a single divinity. However, unlike others, Sant Mat portrayed the divine as an essentially formless God who, unlike Krishna or Brahma, did not enter into incarnation on the earth. Instead, God, without an otherwise anthropomorphic form, came to be represented by the satguru who taught one how to reconnect with the divine source. 


\section{Shabdism and the Sant Mat Tradition}

Some of MSIA's spiritual practices lie within an Americanized version of India's Sant Mat tradition, best known in the West by the Radhasoami sect of Shabdism (Juergensmeyer 1991); for instance, meditation on the sacred sound emanating from God. Somewhat like other Surat Shabd Yoga groups, the Movement teaches "soul transcendence" through the "soul travel" in the "Light and Sound" of God. David Lane (1992) and Andrea Diem (1995) categorize MSIA as one of the newer offshoots of the Shabdism and the Sant Mat tradition, like Eckankar or Divine Light Mission that are also based on the Radhasoami tradition of India. As a tradition, Radhasoami merged out of the influences of many beliefs, and in some circles it has become synonymous with Sant Mat.

The Sant Mat tradition taps deep roots in both Hinduism and Islam (Johnson 1939/1963; Singh 1963). Its original philosophy came alive during the Indian Middle Ages through the work of Guru Nanak (1469-1539), who originated Sikhism. Sikhism advocated Surat Shabd Yoga, the yoga of the Sound Current or meditating on the sound of God. Although Sikhism eschewed Hinduism for its emphasis on ritual, harsh asceticism, and caste system, it retained some cosmology and beliefs, especially karma and reincarnation. Sikhism allowed comparatively greater equality to women, eliminating some of the harsher treatments of women under Hinduism. Historically, Sikhism produced ten gurus, and then declared that its holy scripture (Granth Sahib) would be its only guru.

Although staunch orthodox Sikhs do not recognize offshoots of their religion as valid, other Sant Mat traditions spun off of Sikhism. Mostly notably, the Radhasoami sect retained the practice of gurus. Radhasoami (Fripp 1964; Harper 1972; Babb 1986; Juergensmeyer 1991; Singh 1993; Singh 1994) began through the teachings of Swami Shiv Dayal Singh (1818-1878) in the 1860s, which incorporated ideas from the Indian saints Kabir and Nanak, as well as notions from Nath yoga, Vaisnavism, and personal influences from family and teachers like Tulsi Sahib. Juergensmeyer (1991: 3) cites other parts of the belief as "focused on the efficacy of sacred words and the saving power of a spiritual master in transforming the self and achieving access to otherworldly realms beyond."

Separately from Sikhism, other Sant Mat ideas and practices (Fripp 1964; Harper 1972; Babb 1986; Juergensmeyer 1991; Singh 1993; Singh 1994), a category that includes Shabdism, Radhasoami, and 
Ruhani Satsangi teachings, spread to the West after the 1940s, taking root by the early 1970s. Although there remain theological variations and some minor literal divergences in the different Sant Mat organizations, the same basic tenets are shared by all groups. As mentioned earlier, several structural factors made this possible (Harper 1972; Glock and Bellah 1976; Juergensmeyer 1991; Rawlinson 1997): (1) the printing of Radhasoami and other religious texts in English, (2) the growth and acceptance of new religious ideologies, and (3) the historic relaxation of immigration restrictions against Asians bound for the United States.

MSIA uses only threads of the original Sant Mat fabric. Like religions in the Asian tradition, MSIA members aim ultimately to be liberated from the cycle of death and rebirth. In common with these religions, MSIA accepts the notion that the individual soul is caught up in the material world, which, though viewed less negatively than in classical Hinduism, is all the same less desirable than the state of liberation from this realm. In common with other Sant Mat groups, MSIA pictures the cosmos as composed of many different levels or "planes." At the point of creation, these levels sequentially emerged from God along a vibratory "stream" until creation reached its terminus in the physical plane. The Sant Mat tradition teaches that individuals can be linked to God's creative energy, and that this stream of energy will carry their consciousness back to God. MSIA incorporates some teachings of Radhasoami, which came to the West via the international tours by various Radhasoami teachers (e.g., Kirpal Singh, Thakur Singh, and Charan Singh) and also through Eckankar's teachings. While both Eckankar and MSIA call themselves religions of Light and Sound, Eckankar focuses more on the Sound and MSIA focuses more on the Light and John-Roger's teachings. MSIA, unlike Eckankar, contains a large portion of esoteric Christianity.

Beyond some borrowed practices, MSIA diverges significantly from Sant Mat by not strictly following traditional practices or ideology and by including many other spiritual and psychological philosophies. In an interview (Lewis and Oliver 1995: 110), John-Roger stated that MSIA is neither a Sant Mat group nor a Sant Mat-like group:

[It's] too much NOT like Sant Mat, because when you get further into MSIA teachings, you start to hear things about the basic self, and you get to hear things about [such things as] obsessions and possessions. You don't hear [things like] that in Sant Mat groups. You hear [in Sant 
Mat], "Worship the guru and he will lead you to salvation.” [In MSIA] you hear, “... disregard who's bringing the message."

Unlike Sant Mat, for example, MSIA does not practice strong dietary restrictions, and members generally regard themselves as followers of the Christ Consciousness. Central to the teachings of the Sant Mat tradition is the necessity of a living human master who is competent in initiating disciples into the practice and technique of listening to the inner sound and contemplating the inner light (Surat Shabd Yoga, referred to as "spiritual exercises" in MSIA). While the Radhasoami tradition refers to the living human master with such honorifics as "guru," "Satguru," "perfect master," and so forth, MSIA refers to the teacher as the Mystical Traveler. However, this differs with notion of "guru." The body of the MSIA traveler serves as an anchor for the grand Mystical Traveler Consciousness, and per se the physical bodies of John-Roger and John Morton in turn claim no infallibility or demand any obeisance. Thus, most members treat them as close intimates rather than lofty living god substitutes. The difference then is the consciousness or intelligent energy placed with the teacher, not the teacher's personality or body as such. On this note, we may be splitting semantic hairs because each garners tremendous respect, but historically early in the church's history John-Roger started to dissuade his followers from constructing the traditional guru role around him.

John-Roger's level of involvement with Eckankar seems to be a point of contention for critics (Rawlinson 1997). The parallels between Eckankar and the Movement of Spiritual Inner Awareness have prompted critics to accuse him of plagiarizing Eckankar (Lane 1993, 1994). Rawlinson (1997) mirrors Lane's contentions as does the work of Andrea Diem (1995) who is married to Lane. During an interview with John-Roger (Lewis and Oliver 1995: 37-38), he talked about his relationship with Paul Twitchell, the founder of Eckankar. John-Roger responded:

I've been asked, "Were you a student of Eckankar?" Yeah, if you can consider I was a student of the Reader's Digest and National Geographic and the Rosicrucians and some other churches all at the same time. I went to some of the churches to see what they did-[I was what they refer to as] a metaphysical tramp. I call those my "metafizzle" days because none of those ever worked out. No way do I have anything negative with Eckankar. No way. I had a private interview 
with Twitchell, and he said, "You have the sound [and] the names of the Gods on every realm." I said, "They're all the same God, it's just a different vibration." He said, "You know them?" I said, "Sure I know them." And we discussed the initiation words, and he told me a sampling of his. And I said, "I don't use those, I use the five names." And he said, "Well, I don't think the people will understand the five names." I said, "Not unless you give them to them," because he wasn't going to give it to them. I got a letter a month later that said, "Since you're an initiate of the Sound Current through Eckankar, here's the other information that you're to get." So I looked through the information, and I said, "I don't know why I got this, because I wasn't initiated."

John-Roger thus acknowledges that he fraternized with Eckankar, but he was not, according to his own account, ever formally initiated into that organization. As for the parallels between Eckankar and MSIA, both drew on some previous teachings associated with Sant Mat. However, from MSIA's standpoint, it went far beyond those teachings by following the spiritual guidance of the Mystical Traveler through John-Roger and his chosen successor John Morton. Furthermore, history tells us that most new religions encapsulate parts of older religions in their theologies; for example, the Old Testament became part of the Christianity's Bible, and so this type of repackaged synthesis is rather common. The controversy hinges upon issues of territoriality and bona fide transmission of the authority to spread particular teachings.

\section{Esoteric Christianity}

Like Eastern mysticism, esoteric Christianity gained notice in the nineteenth century and spread to various pockets of alternative religion. Esoteric Christianity has no solid definition because it seems based on an array of writings and apocryphal ideas. Generally speaking, esoteric Christianity stems from the notion that established churches did not teach the deeper wisdom or arcane knowledge of the true nature of Christ. This is a situation MSIA founder John-Roger (1981b) dubbed as churchianity. Historical and archeological records show that canonical Christianity threw out many extent gospels (e.g., the Secret Gospel of Mark, the Gospel of Thomas, and the Gospel of Mary Magdalene) and rejected diverse interpretations regarding the teachings of Jesus (e.g., Gnosticism). Esoteric Christianity seeks to reclaim hidden mysteries and lost writings. Other views of esoteric 
Christianity stress its oneness with other religions like Hinduism or Buddhism, even in some cases claiming that Jesus traveled to India to learn from the mahatmas.

The expression, esoteric Christianity, is commonly linked with the Rosicrucians and the idea of a mystery school with several levels of initiation to secret knowledge (Melton 1990). Max Heindel founded the Rosicrucian Fellowship in 1907. On the other hand, Theosophist Annie Besant wrote an early work called Esoteric Christianity or the Lesser Mysteries in 1914. Anthroposophist Rudolf Steiner originally published Exoteric and Esoteric Christianity in 1922. This shows that such ideas were not confined to one group.

The concept of esoteric Christianity usually stresses the authority of inner experience and direct personal access to Christ. The idea of a Cosmic Christ, now so popular in the New Age movement, came from such earlier teachings; the Cosmic Christ differs from the historically defined Jesus Christ of orthodox Christianity. The Cosmic Christ resembles more of an intelligent energy and loving consciousness that refrains itself from judgments, designations of sins, or assignments of damnation. Certain believers espouse the existence of a planetary Christ, equivalent to the legends of Lord Maitreya in the East. In later explanations of MSIA's philosophy, the reader will see the connections to this possible influence from John-Roger's early studies and from the sentiments of free-floating New Age ideas. Today some New Age circles tout their alternative schools as mystery schools (e.g., the Ancient Egyptian Mystery School of Toth, Noegenesis Mystery School for the New Millennium, and the Amenti Mystery School), the reclaimers of secret cosmological knowledge. Mystery schools connote an extraordinary otherworldly transmission of arcane knowledge; in some groups, the term implies that a student travels out of the body to learn lessons in other realms of reality. Certain members of MSIA said they considered their group more a mystery school than a conventional church or religion. Despite its other idiosyncratic positions on Christ and conventional Christianity, MSIA retains the traditional Christian ideal of forgiveness.

\section{New Thought}

New Thought philosophy generally teaches that negative thoughts and speech cause disease and disharmony in one's life (Melton 1990); in other words, negative thoughts and speech attract negativity or can 
manifest what one fears. In some of its many variations, it incorporates esotericism with spiritual self-help healing. It was devised by a student of Christian Science, Emma Curtis Hopkins (1853-1925), who laid the groundwork for broader teachings about mind power, positive thinking, and self-healing and self-improvement through thought reformation. She instructed Phineas Parkhurst Quimby (1821-1910), the man who is usually given credit as the founder of New Thought. Its ideological offshoots may be more familiar: Divine Science, Science of Mind, Religious Science, and Unity. According to Melton (1990), it preached a gospel of happiness, prosperity, and boundless optimism to a growing American middle class.

One historic connection to New Thought was when John-Roger learned aura balancing at the Quimby Center in New Mexico from Neva Dell Hunter and Ellavivian Power in the 1960s. He adapted what he learned into an MSIA service, and Ellavivian would later become an MSIA minister (Tumminia 2005). New Thought, like many other previously mentioned metaphysical teachings, dovetailed into different sectors of New Age philosophy and into MSIA (Melton and Lewis 1992; Lewis 1998b; DeChant 1999), especially in the areas of prosperity consciousness and the practice of doing affirmations, commonplace customs in MSIA (John-Roger 1988).

\section{New Age Ideas}

In the 1960s, hippies sang about the dawning of the Age of Aquarius, and astrologers announced its importance. Many early spiritual teachers such as Annie Besant (1847-1933) and Alice Bailey (1880-1949) talked about a New Age coming, but by the mid-1970s some people were finally doing something about it (Roszak 1975; Melton 1992; Heelas 1996; Sutcliffe 2004) in the form of a burgeoning acceptance of nontraditional healing, living, and spirituality. In 1980, Marilyn Ferguson published The Aquarian Conspiracy, which was for many a great summation of the wide-ranging notions that comprised the New Age movement (Melton 1992) and alternately called the New Age milieu (Sutcliffe 2004). The sociocultural nursery (American metaphysics), out of which parts of MSIA teachings would emerge, cultivated New Age ideas, especially in terms of the validity alternative forms of education and religion.

The New Age philosophies synthesize many different preexisting practices, cosmologies, and strands of thought. In the early 1970s, 
some saw the prominence of newly imported Asian groups as a feature of New Age energy, although many of the older esoteric-metaphysical organizations also experienced growth spurts. These various groups, in combination with a significant number of less formally affiliated individuals, constituted a fairly substantial spiritual subculture that became the successor movement to the counterculture. This initial phase of the New Age networking looked forward to the transformation of society, but did not place an emphasis on many of the things that outside observers now regard as quintessentially New Age (eclecticism, unconventional healing, channeling, amulets, charms, magical thinking, and the stereotypes of moon-yodeling weirdos).

From one angle, New Age activity can be viewed as a successor to the counterculture of the 1960s. As observers of the New Age vision point out, a significant portion of New Agers are baby boomers, people who two decades earlier were probably participating, at some level, in the phenomenon known as the counterculture, if only at the level of fashion and popular music. As the counterculture faded away in the early 1970s, many former hippies found themselves embarking on a spiritual quest, one that, in many cases, departed from the Judeo-Christian mainstream. Thus, one of the possible ways to date the beginnings of the New Age expansion is from the period of the rather sudden appearance of large numbers of unconventional spiritual seekers in the decade following the 1960s. However, most scholars see its roots going farther back in time.

The New Age milieu, narrowly defined, can be seen as an esotericmetaphysical revivalism generated among independent British theosophists in the post-World War II generation, which spread through the well-established networks in the 1970s (Melton 1990; Melton and Lewis 1992). Through the 1980s, the popular milieu grew enlivening the older metaphysical community from which both drew many new adherents, greatly assisting the spread of mystical practices, such as astrology and meditation, and Eastern ideas such as reincarnation into the general population far beyond the boundaries of New Age activity proper. If the New Age milieu ranks more than just a flaky survival of the hippie counterculture, then what is it? New Age activities can be viewed as revitalization activity within preexisting metaphysical-occult networks (Melton 1990; Melton and Lewis 1992; Sutcliffe 2004). As such, the New Age can be compared with Christian revivals, particularly with such phenomena as the early Pentecostal movement (i.e., a movement that simultaneously revived and altered a segment of Protestant Christianity). Comparable to 
the influence of Pentecostalism on Christianity, the New Age had an impact on some but not all segments of metaphysical religion. Also like Pentecostalism, the New Age revival left a host of new organizations/denominations in its wake (Lewis 1998b).

Suttcliffe (2004) dates the New Age nascence to the 1930s, defining it as diffuse collectivity of seeker networks responding to loosely strung together ideas about millennial changes. Narrowly considered, a strong wave of New Ageism can be traced to England in the late 1950s where a new revival of older mysticism took place. At that time, the leaders of certain independent esoteric groups heavily influenced by the reading of theosophical authors, especially Alice Bailey, began to meet to discuss the possible changes coming during the last quarter of the twentieth century. Those meetings continued through the 1960s and, as they grew, came to include their most well-known participants, the founders of the Findhorn Community in Scotland. By the 1970s, a vision of the New Age coalesced, reaching out to like-minded people around the globe. The work of Anthony Brooke and the Universal Foundation greatly assisted the process of spreading the many ideas. Brooke toured the world, contacting occult and metaphysical groups, and created the first international networks of New Age believers.

Sometime after 1965, David Spangler, a student of the Alice Bailey writings, toured the country doing counseling and lecturing (Melton 1992). When in Los Angeles, he interacted with the Fellowship for Universal Guidance working on his concepts, eventually publishing booklets. There, Spangler channeled the spirit of "John." He traveled to England in 1970 and then stayed in Scotland at the Findhorn community for three years. Findhorn eventually gained worldwide fame as a countercultural center that espoused astrology, spirituality, community cooperation, and contacting nature spirits to help grow large vegetables. Upon his return to the United States, Spangler began to author a series of books, which laid out the hopes and aspirations for a transformational era. In an interview (Jones et al. 1998), John-Roger said that he knew Spangler and once lent him money. This is not to suggest the John-Roger derived his ideas from Spangler, but rather to suggest that the blossoms of New Age ideas were cross-fertilized in subcultural pockets and within various networks of acquaintances.

One can pinpoint certain essential ideas that came to characterize the New Age networks of seekers. None are particularly new ideas, their distinctiveness being brought together in a new gestalt (Lewis 1998b: 51-54) 
1. The possibility of personal transformation. New Age philosophy offers the possibility of a personal transformation in the immediate future. While personal transformation is a common offering of spiritual groups, the New Age millennial expectations offered a new immediacy, which had been lacking in other teachings. The transformative process was linked to the healing process of the individual, either of a chronic physical problem or of a significant psychological problem. Healing then became a metaphor of transformation possible in the New Age, a heal-yourself-heal-the-world belief. Not too distant from this belief, the emphasis on transformation and inner healing (healing blocks to soul awareness) are clearly evident in MSIA's teachings.

2. The coming of broad cultural transformation. The New Age offered the hope that the world, with many people, especially those on the edges of the dominant culture's negative expression, would be swept aside and replaced with a golden era in the next generation. As articulated by keynoters, like David Spangler, the hoped-for changes are placed in a sophisticated framework of gradual change relying upon human acceptance of the new resources and the creating of a new culture. A watershed in human history has been reached with the advent of modern technology and its possibilities for good and evil. At the same time, because of unique changes in the spiritual world, symbolized and heralded (but not caused) by the astrological change into the Aquarian Age, this generation has a unique bonus of spiritual power available to it. This additional spiritual energy, operating on the world and its peoples, will make possible the personal and cultural transformation that will usher in a New Age. Some segments of the milieu wedded themselves to environmentalism, peace movements, animal rights, women's rights, and cooperative forms of social organization.

3. The transformation of esoteric arts and processes. New Agers rediscovered older practices from astrology to tarot and from mediumship to psychic healing. Yet the significance of these practices has been significantly altered. Astrology and tarot were no longer fortune-telling devices but tools for self-knowledge. Mediumship became channeling, in which the primary role of the medium was to expound metaphysical truth, rather than to prove the continuance of life after death. Psychic healing became spiritual healing, a metaphor for one's relationship to life and the cosmos.

4. The self as Divine. Within the New Age, one theological affirmation that has found popular support is the identification of the individual with the divine. Underlying this notion, which finds a wide variety of forms, is a monistic world in which the only reality is "God," usually thought of in predominantly impersonal terms as Mind or Energy. This New Age tenet shares much with traditional Upanishadic Hinduism, as discussed earlier. Again, MSIA is clearly in synch with this dominant 
idea of New Age thinking, although its teachings go further and point to the possibility of having a personal, loving relationship with God. In MSIA, the true self, the soul, is divine.

John-Roger politely distinguishes his teachings from those of the New Age, indicating that rather than being New Age, MSIA encompasses a new way of looking at ancient ideas (Lewis 1998b). To outside observers, there appears to be a cross-pollination of ideas and practices. Emerging in the 1970s, some of the earlier New Age healing techniques dealing with different aspects of the self were adopted by MSIA, such as aura balancing, which is a technique for clearing the auric (spiritual plasmic) field that exists around each individual (influenced by Neva Dell Hunter); innerphasings, a technique through which the individual can reach into the subconscious and bring to consciousness and remove the dysfunctional patterns learned early in life; and polarity balancing, which releases blocks in the physical body. Massimo Introvigne (1998) equates MSIA with Paul Heelas' concept of a New Age seminar religion (1996), a type of spirituality that focuses on personal experience and psychological exercises aimed at self-knowledge and self-improvement.

Possibly the most widely practiced New Age transformative tool is meditation (in its many varied forms) and related tools of inner development like creative visualization. In its utilization of meditation, the New Agers borrow insights from the findings of the human potential movement and transpersonal psychology, both of which demonstrate that techniques of meditation and inner development could be detached from the religious teachings in which they were traditionally embedded. Thus, one could practice Zen meditation without being a Buddhist and yoga without being a Hindu. That insight made all of the Eastern and metaphysical techniques immediately available to everyone without the necessity of their changing self-identifying labels before their use. MSIA generally aligns with the New Age reinterpretation of meditative techniques although the organization has not made the other seriously occult arts part of its teachings and it specifically cautions against giving up responsibility for making one's own decisions by going to psychics, fortune-tellers, or anyone outside of oneself. Nor does it advocate channeling. Outsiders may interpret such things as part of MSIA yet it would readily point out the difference as the source of the origin of energy within these acts.

On the theme of transformation within the New Age, MSIA takes a position of neutrality. While many church members clearly work to 
improve society, MSIA as an organization focuses on "soul transcendence" rather than activist world transformation. However, it does espouse that when individuals raise their shared consciousness, it will assist others in becoming peaceful and loving, which represents another thread of New Age thinking. Individual members may join any social movement they want and "be of service" to worthy causes; nonetheless, the MSIA remains aloof from political and social issues. Once it did honor a very political man, Lech Walesa, who led a working-class rebellion as president of the Solidarity union that fought against the Polish state in the 1980s, with an Integrity Award, in 1986. Ordinarily, MSIA does not involve itself with civil matters such as union activism, preferring to concentrate on spiritual matters rather than liberation theology. Walesa was honored as a man of integrity.

At this point, the reader may well be asking, "What does the proliferation of alternative religious subcultures mean for society as whole?" There have been a variety of historical periods during which religious innovation flourished. In the West, there was a proliferation of a new religious consciousness in the late classical period, as well as in the wake of the Reformation. In the United States, historians have noted a recurring pattern of religious awakenings, beginning with the Great Awakening of the 1740s. The most general observation we can make is that periods of renewed spiritual activity occur in the wake of disruptive social and economic changes. When the established vision of status quo no longer seems to apply, people begin searching for new visions. In previous cycles of American religious experimentation, innovative forms of Protestantism often formed the basis for these new visions. As revivalist fervor died down, new or reinvigorated Protestant denominations became the pillars of a new cultural hegemony. Contrary to the static reputation that religion has in general as defenders of the status quo, the general spiritual landscape contains dynamic social forces that work to shape and reshape the topography. New religions usually sprout from older ones by hybridizing previous ideas into blossoming new philosophies, one of which is MSIA. The roots of the purple rose run wide and deep.

\section{About the Book}

Qualitative sociology endeavors to convey the ways that members of groups see their reality. This research studied the cultural ethos and uses of meaning in the Movement of Spiritual Inner Awareness, a relatively new faith that displays a syncretistic postmodern assortment of 
religious traditions and spiritual innovations. Although MSIA departs from conventional religions in some ways, it also shares a great deal with established traditions. In many ways, Movement members do what other people around the world do. They pray, and they worry about their families and finances, looking to spiritual intervention for comfort and relief. They yearn for miracles, and they relate to the mystic promise of supernatural contact. They hope to feel more peace and to go to a better place when they die.

Any religion erects boundaries of beliefs not shared with outsiders; within every religion meaning systems create differentiated worlds of experience. In the cultural atmosphere of MSIA, followers value love and spiritual energy believed to be emanating from the soul and beyond. As an extension of this value system and imagery, norms aimed at fostering positive expression frame the way members communicate and order their thinking. As in any utopian vision, the results may be less than perfect, but Movement people hold to the normative guidelines in order to "experience the loving." In visions of self or of the spiritual teacher, the notions of unconditional love extend to the others and take precedent in internal dialogues. Because of the human difficulty of maintaining such expression, MSIAers take classes aimed at psychological introspection and self-improvement, which is believed to fuel spiritual energy.

Although considered controversial by some because of its unconventional approach, MSIA endures because members still resound with its philosophy that utilizes many types of alternative knowledge and experiential interpretation heretofore rejected by the Western mindset. Its amalgamation of previously disparate themes, like Christianity, folk animism, Eastern religion, and New Age thought, exemplifies a turn-of-the-millenium acclimatization facilitated technologically by electronic means and by interactional communal engagement. This adaptive process of reformulating and synthesizing ancient spiritual themes into contemporary approaches characterizes MSIA activities, and it remains a key factor in its appeal to those who choose it as a spiritual practice. Moreover, this type of synthesis may indicate an embryonic evolutionary trend in twenty-first-century religion.

Despite public criticism, Movement members continue to find its philosophy meaningful at the most and pragmatic at the least. MSIA appears to be in a period of stability although without any significant growth in the number of members in the last seven years. When and if MSIA will be shifted from the new religion category to an accepted religious sect is still unknown. Other questions remain. What are the 
sociological attitudes and beliefs of members? Will MSIA continue to attract significantly more numbers? Will children born into the Movement stay in the group when they come of age? What will happen after the death of their founder? Will the MSIA prove adaptive and resilient to future trends in religion? Only some of these questions will be answered by this book. 
This page intentionally left blank 


\section{Chronology}

1934 Roger Hinkins was born on September 24 in Rains, Utah. Late 1930s-He grows up in a mostly Mormon community, but later says the Mormonism had "zero" influence on his later spirituality (Introvigne 1998: 3). John-Roger once told a story about how his parents fooled him and his brother by leaving coal in their Christmas stockings (Tumminia p2010). Afterward, his parents showed the children their real presents.

1940s Late 1940s to early 1950s, Hinkins attended high school in Huntington, Utah.

1951 John Morton born in Las Vegas, Nevada.

1952 About this time, Hinkins attended Carbon College for two years in Price, Utah (Introvigne 1998).

1957 Hinkins' brother severely burned. Later Roger Hinkins underwent surgery to remove tissue growing out of his nose and eyes. During surgery, he received the first part of the Mystical Traveler Consciousness (John-Roger 1981b).

1958 During surgery on the same condition one year later, Roger Hinkins received the second part of the Mystical Traveler Consciousness (John-Roger 1981b).

Hinkins earned a bachelor's degree in degree at the University of Utah in 1958.

Late 1950s During the middle to late 1950s, Hinkins did Light studies for people during his time at the University of Utah and in San Francisco (Lurie and MSIA 1999). He had psychic experiences, stating, "I was psychic as all get-out, but I had not yet opened my spiritual eye" [quote from Tumminia research notes, 2006]. Hinkins worked a number of jobs, once as a credit investigator.

Hinkins did not attend the Mormon Church after getting a university degree in the late 1950s (Lurie and MSIA 1999). 
1960 John Morton moves to Sacramento with his family.

Hinkins moved to Los Angeles and taught high school in Rosemead.

1963 Hinkins was in car accident and subsequently underwent a kidney operation. While in a coma, he receives the John consciousness and the third part of the Mystical Traveler Consciousness (John-Roger 1981). He (Lurie and MSIA 1999: 2) receives the mantle and keys on the spiritual realms from sacred beings, "MANY KNOWN TO US, AND MOST OF THEM UNKNOWN TO US" (original text capitalized). One of those beings was John the Beloved (Lurie and MSIA 1999: 3). John-Roger also said he met with the spiritual hierarchy. When he awakened from his coma, he felt the presence of "John" speak inside of him (John-Roger 1981b).

1963 After he had a spiritual reading with two channelers, he changed his name to John-Roger- J-R for short (Introvigne 1998).

Candy Shanklin, then fourteen years old, met Mr. Hinkins, the high school teacher. Shanklin would become an assistant, minister, later Insight trainer and coordinator.

Jsu Garcia born on October 6 in New York City.

1960s (no specific dates)-Hinkins explores many religious traditions and philosophies. He had contact with the Fellowship of Universal Guidance in Glendale (Melton 1999), which emphasizes the importance of the three selves. John-Roger was acquainted with New Age ideologue David Spangler, and they spoke on various occasions (Melton 1990). He later visited Findhorn in 1971. John-Roger heard about Neva Dell Hunter, psychic and teacher, and he decided to stop in on a cross-country trip.

John-Roger got an aura balance at the Quimby Center in Alamogordo, New Mexico, and learns aura balancing from Ellavivian Power. John-Roger adapted aura balancing to his approach, and Ellavivian adopted John-Roger's method to her technique.

One MSIA member stated he met Hinkins at a flying-saucer conference.

1967 Jack Reed (1972: 6) met John-Roger at a "Light" (metaphysical) conference, and thought he was a "weird dude." 
Genie Lucille Ford met John-Roger. She later became an important part of the LA Ministerial Board's executive committee.

John-Roger read material from Eckankar. He emphasized that he was never a "formal member" of Eckankar; it was just one of the groups he explored. As stated in Lurie and MSIA (1999: 2), "J-R just never renewed Eckankar Discourses."

John-Roger and Pauli McGarry (Sanderson 1988) went to Disneyland, where he revealed his spiritual side and visions of spreading his wisdom.

1968 John-Roger started giving seminars. First seminar began on May 4. Price of seminar was $\$ 3$ for one person and $\$ 4$ for a married couple.

1969 John-Roger arranges that his seminars are taped, and then the fledging group sells them. Since many people do not own tape players at that time, seminars transcripts become "discourses," booklets that contain the teachings. The first prints consisted of about 30 copies (Sanderson 1988; Introvigne 1998).

Larry Hartstein (now Laren Bright, MSIA, LA Ministerial Board advisor) met John-Roger.

Carolan Nathan went to a MSIA seminar in Miami. In 1971, she returned to England and with her brother Nicholas Brown gave home seminars. In 1973, the first ministerial board outside the United States was formed with Carolan Nathan, Nicholas Brown, Nathalie Franks, and Paul Kaye.

1971 John-Roger's mom, Erma Hinkins died. John-Roger quit his job teaching high school. MSIA formally incorporated in June 1971. Price of seminar was $\$ 3$ for one person and $\$ 4$ for a married couple. Discourses, which at first were mimeographed, cost $\$ 40$ per year. Eleven other booklets were available at a cost of $\$ 2$ to $\$ 3$ each.

The idea for the MSIA ministry takes shape. First ministers officially ordained in 1971.

Paul Kaye introduced to the Movement. Paul met John-Roger in 1972, and he was ordained in 1973.

In October, MSIA published its first official newsletter, On the Light Side (eight pages for 25 cents), which touted the work of Dr. John Roger Hinkins (no hyphen in the original).

1972 In July, members rent the Light Castle in Whittier, California. John-Roger's father, Parley, died. 
1973 According to The Movement newspaper, John-Roger visited San Diego (March 25-27), giving a live seminar at the home of MSIA ministers Dick and Rhoda Leight. Staff members Wes Whitmore and Edgar Veytia performed aura balances and innerphasings.

John-Roger invited all ministers to come to LA on March 10 to elect an administrative board. Seven people became the officers in the newly formed LA Ministerial Board: Genie Ford, Muriel Engle, Reuben Paris, Ted Drake, Herbert Holmes, Henry Conyers, and Wanda Mansbach.

The first national minister's meeting held at the Light Castle on June 16 with 143 ministers listed.

In September, a group of MSIA people, John-Roger and staff, visited Sathya Sai Baba in India.

Sri John-Roger title used, but later dropped.

Maria Elena Kittleson asked John-Roger if she could bring the Movement to Mexico and John-Roger said yes.

1974 MSIA purchased the former Guasti Villa for ashram, office, and seminar space. MSIA renames it Prana (Purple Rose Ashram of the New Age).

1975 Mark Lurie introduced to MSIA through a high school activity on religion. He spent for discourses with his high school graduation money. Lurie would later volunteer, and then become an integral staff member, eventually part of the MSIA Presidency.

Baraka Holistic Healing Center founded.

1976 John-Roger incorporates Koh-E-Nor University. Koh-E-Nor means Mountain of Light.

1977 First author introduced to MSIA in San Diego, California, by roommate.

PTS founded and headquartered at Prana.

1978 Donation for a live MSIA seminar at Prana was \$4 for one person. During January 4-8, first Insight Training led by Russ Bishop held in Santa Monica with 150 participants. John-Roger and staff visit Florida, Washington, DC, New Jersey, New York, Boston, Minneapolis, and Aspen in their spring travels.

On November 18, John Morton receives ordination in Los Angeles around the time he took Insight II at Sheraton Universal hotel. 
1979 Mary Hulnick has a dream that she and Ron would breathe life into Koh-E-Nor University. They ask for a meeting with John-Roger to offer their services. Koh-E-Nor starts operation (Hulnick and Hulnick 2010).

Rev. Andrew Baillie started up the Spanish language department for translating MSIA materials.

The Heartfelt Foundation, established by Patti Rayner, is a volunteer-driven nonprofit association dedicated to serving and assisting people in any form of hardship, such as the homeless, needy families, and disaster survivors.

Prana sells t-shirts emblazoned with a large purple rose.

1980-1 Ron and Mary Hulnick teaching at Southwestern College. Ron had become a devoted student of Neva Dell Hunter.

1981 John-Roger puts up some money for Sant Mat guru, Baba Faqir Chand, to tour the United States (Anonymous 1999b). Baba Faqir Chand dies during the trip.

1982 Mark Lurie joins the MSIA staff after graduating from college.

John-Roger Foundation established.

Koh-E-Nor University graduates first class of eleven students (Hulnick and Hulnick 2010)

The Institute for Individual and World Peace (IIWP) incorporates as a separate foundation along with the purchase of Windermere Ranch in the Santa Inez foothills above Santa Barbara. Its goal was to set up peace studies, using the ranch as a retreat space.

1983 The first author ordained a minister in a gathering at a home in Rancho Santa Fe, California.

Integrity Foundation incorporated. First Integrity Award banquet held.

From 1978 to 1983, David Lane and John-Roger had a friendly relationship. In 1983, Lane met with "4 or 5 defectors of JohnRoger” in a secret meeting in Santa Monica (Anonymous 1999b: 11). Thus, the David Lane controversy started.

1984 Betsy Alexander joins MSIA staff. MSIA organizes his first PAT IV trip. There came to be about ten PAT trips, including PAT V in 1990.

1985 After functioning primarily as an administrative body, the LA Ministerial Board provided ministers with more direct contact. 
At the Conference of Giving, John Morton received the keys to ordaining others into the church. In MSIA vernacular, he was given the earth mantle of ordination.

1986 The John-Roger Foundation gave international Integrity awards to Lech Walesa, Stevie Wonder, and Ken Kragan. Because of political controls on him, Walesa could not attend, but some MSIAers made the arduous trip to Poland to tape his acceptance. The attendees of the gala award ceremony viewed his speech.

1988 Koh-e-nor (means Mountain of Light) University changed its name to University of Santa Monica.

John-Roger escorts Sally Kirkland to the Oscar ceremony, where she was nominated for Best Actress for her role in Anna.

John-Roger passed the keys of the MTC to John Morton on June 19, at 3:28 p.m. at the Minister's Meeting in Los Angeles, California. John Morton had been on staff for nine years.

John-Roger and staff travel to Russia and then to Germany where John-Roger put a "Light worm" in the Berlin Wall. Berlin Wall was taken down by the people the next year.

In July, The Movement newspaper changed its name to the New Day Herald.

Los Angeles Times printed a negative article on JohnRoger and MSIA on August 14, and Jack Reed responds in Movement newspaper.

In September, a People magazine article allegesed certain improprieties by John-Roger based on accusations of disaffected members.

1989 Presidency of MSIA passes to Paul Kaye, Vincent Dupont, and Mark Lurie.

1990 The city declared Prana a Los Angeles Cultural Heritage Monument. PAT V goes to the Middle East.

1992 Reuben Paris died on September 11.

1994 Northridge earthquake damages Prana. MSIA decides to retrofit and refurbish Prana along with the grounds.

1994-96 Peter McWilliams controversy flairs up.

1995 John-Roger and the PAT IV group of over 300 people traveled to Athens, the Acropolis, Turkey and Asia Minor.1996-Ken Jones and Carol fell in love and married in 1996. 
A Los Angeles area minister dying of AIDS appealed for assistance at a meeting. This event inspired the founding of HeartReach within the Heartfelt Foundation, which focuses on the needs of the elderly and the dying in MSIA. Cult Awareness Network (CAN) filed bankruptcy because of legal costs brought about by lawsuits filed against it by Scientology and other groups, including MSIA, for religious freedom. Ironically, Scientology bought the assets of CAN including its files and documents.

Life 102: What to Do When Your Guru Sues You by Peter McWilliams declared out of print by Prelude Press. MSIA owned the copyright after a legal contest.

$1997 \quad$ MSIA had 2577 ministers worldwide, including 738 in California and 459 in Mexico and South America.

Rev. Muriel Engle died in March.

The first year of DSS completed without a graduation ceremony. The graduation ceremony created later.

1998 Seeking the Light by James R. Lewis published.

John-Roger produced the movie short, My Little Havana, written by Jsu Garcia. It starred Jsu Garcia, a minister and staff member.

1999 In August 1999, Peter McWilliams offered to write a letter, on behalf of MSIA, to someone who had put LIFE 102 on their website without permission from the copyright holder.

$2000 \quad$ Peter McWilliams died in June.

Labyrinth built at Prana.

John-Roger and followers toured the Great Wall of China.

2001 After September 11, MSIA prayed for all those involved. John-Roger, John Morton, Jsu Garcia and others visited New York in December, where they placed Light Columns at the devastated site of the World Trade Center.

2002 On January 15, John Morton came to Sacramento, California, where he gave a workshop $\mathrm{He}$ and his followers walked through the state capitol planting Light Columns.

At Prana, second phase of Peace Gardens started.

MSIA purchased MacGowen Mansion, renamed it, Prana

West. Retrofitting, repair, and restoration began. 
2003 PAT I held in Jacksonville, Florida. MSIA convened the Conference of Momentum: Letting Love Lead. John Morton stated that John-Roger was his ministry. Joan Shea and Deborah Martinez received Minister of the Year awards.

2004 Prana West was being renovated for more living space for votaries, office space, and rooms for classes.

Minister Ellavivian Power died.

In March, 200 people committed to holding the 32-day focus for peace for IIWP's annual Worldwide Peace Prayer.

On October 31, John-Roger fell down the stairs at his home in the early morning hours gashing his left eye on a picture frame. Jsu Garcia and others rushed him to the hospital where one doctor said the eye was too damaged and that it had to be removed. Garcia, John Morton, and others prayed for a miracle. They finally found a doctor who could repair the eye and reattach the retina. Thus, John-Roger's eye was saved. Pictures of him after this time showed a slight asymmetry in the eyes.

2005 Conference of Gratitude held at Sheraton Universal Hotel. At the annual minister's meeting, 827 attended from all over the world. At the initiates meeting, 900 participated.

Sally Kirkland teaches an acting class at Prana. Spanish language MSIA classes were held twice a week at Prana.

Prana hosts some Spiritual Spa days where people can visit the meditation garden and walk the labyrinth at Prana.

On September 13, IIWP cosponsored and supported the Annual Interfaith Prayer Service in honor of the Sixtieth United Nations General Assembly at St. Bartholomew's Church in New York City. Leigh Taylor-Young represented IIWP.

2006 In an effort to transition to more digital media, MSIA started to phase out the selling of audiotapes and videotapes in favor of CDs, DVDs, and MP3s.

On May 16, the movie, Spiritual Warriors, premieres at the NuWilshire theater in Los Angeles. The film stars Robert Aston and Jsu Garcia with supporting roles by Leigh TaylorYoung and Sally Kirkland (the last three actors are ministers and prominent members of MSIA). Based on The Spiritual Warrior book by John-Roger, the film allegorically describes the relationship between John-Roger and Jsu Garcia, who wrote the screenplay and headed the production team. 
The annual meetings and workshops held in late June and early July at the Sheraton Universal called the Conference of Living Love. The ministers' meeting hosted 800 ministers.

July 8 Spiritual Spa Day theme at Prana was titled Playful Parenting.

July 13 Rock singer, Meatloaf, filmed a music video at Prana.

Ronald Hulnick received a letter from a woman at Chowchilla State Prison. USM started the Freedom to Choose Service Project that gives free workshops in soul-centered education. USM graduates share the principles and skills they learned. The project resulted in a documentary film, Freedom to Choose.

2007 Opening of Prana West after extensive remodeling, rehabilitation and retrofitting. Conference of "Spiritual Promise" held.

2008 Conference of "The Rest of your Life" held from July 2-6.

2009 Israel trip for Founder's Day. Sometime during that year, John-Roger appeared to be close to death. A worried staff called his brother, Delile, who arrived quickly to be with his younger brother. Delile whispers something in JohnRoger's ear about the blessing of Melchizedek priesthood. Miraculously John-Roger recovered quickly.

2010 Ken Jones, Rhoda Leight, and Ray Zumwalt pass away.

Filming started on The Wayshower. John-Roger and Garcia finished their second feature film in September 2010, as cowriters, coproducers, and codirectors on the project. The Wayshower stars Eric Roberts, Peter Stormare and Sally Kirkland, and was filmed on location in Utah, Morocco, England, France, Spain, and Peru.

Founder's Day (September 24) celebrated with a trip to Morocco. Two busloads of votaries were stranded in the desert when one bus broke down. During trips to the Kasbahs, MSIAers dodged motorcycles and donkeys.

2011 Founder's Day (September 24) celebrated at Gleneagles resort in Scotland.

The Wayshower toured film festivals and gave other private screenings, for example, at the MSIA conference. Pauli Sanderson lit up the stage as she told stories about the early days and about John-Roger during the Conference of the Wayshower. 
2012 PTS PAT trainings planned for Los Angeles, Philadelphia, Jacksonville, Mexico City, Buenos Aires and Bogota, Columbia.

Some PTS classes planned are Free Form Writing, Spiritual Principles of Health and Well-Being, and tele-workshop in Spanish, The Power of Intention. In addition, PTS offers Master of Spiritual Science in English and in Spanish and Doctor of Spiritual Science courses in English.

On March 17, Insight University holds a benefit to support youth in becoming transformational leaders, featuring Arianna Huffington at UCLA's Royce Hall.

On April 6-7, John Morton facilitates Walking in the Light workshop at 2101 Wilshire Boulevard.

On April 8, MSIA held Easter celebration at Santa Monica beach from 10 a.m. to 1 p.m.

In July, Conference of One Accord held at Sheraton Universal hotel.

In September, Founder's Day celebration planned at Bovey Castle, England. Other events and a fundraiser scheduled for London, including the sneak preview of the new movie Mystical Traveler: The Life and Times of John-Roger, which was due to be released in 2013.

2013 John Morton and Leigh Taylor-Young wed at a ceremony on New Year's Day. The Conference of the Mystical Traveler took place in July. 